\title{
ANALISIS TINGKAT KEMAMPUAN BERPIKIR KRITIS SISWA SEKOLAH DASAR DITINJAU DARI TINGKAT KEMAMAMPUAN MATEMATIKA
}

\author{
Nur Fitri Amalia', Leni Nur Aini², Syukron Makmun ${ }^{3}$ \\ 1,2,3 Universitas Zainul Hasan Genggong Probolinggo \\ corespondence email: nurfitriamalia188@gmail.com
}

Received : June 9, $2020 \quad$ Revised: June 11, $2020 \quad$ Accepted : June 13, 2020

\begin{abstract}
ABSTRAK
Penelitian ini bertujuan untuk menganalisa kemampuan berpikir kritis siswa Sekolah Dasar ditinjau dari Tingkat Kemampuan Matematika, mengetahui kendala serta usaha yang dilakukan guru dalam mengembangkan kemampuan berpikir kritis siswa. Subjek penelitian adalah siswa kelas V SDN Jember Lor 1 yang berjumlah 26 Ssiswa. Teknik pengumpulan data yang digunakan meliputi wawancara, observasi, tes dan dokumentasi. Data dianalisis menggunakan statistik deskriptif dan deskriptif presentase secara individu, klasikal dan perindikator.

Hasil penelitian menunjukkan kemampuan berpikir kritis siswa Sekolah Dasar ditinjau dari kemampuan matematika siswa berada pada kategori sedang dengan ratarata klasikal 71,8. Terdapat $50 \%$ siswa berada pada kategori berpikir kritis tinggi, $30,8 \%$ siswa pada kategori berpikir kritis sedang dan 19,2\% siswa berada pada kategori rendah.

Kendala yang dialami guru dalam mengembangkan kemampuan berpikir kritis siswa yaitu beberapa siswa masih belum terbiasa berpikir secara sistematis, siswa belum terbiasa memberikan alasan dalam menyelesaikan soal atau cenderung yang penting mengacu pada rumus.
\end{abstract}

Kata Kunci : Berfikir kritis, Matematika, Kemampuan

\begin{abstract}
This study aims to analyze the critical thinking skills of elementary school students in terms of the level of mathematical ability, knowing the constraints and efforts made by the teacher in developing students' critical thinking skills. The subjects of the study were the fifth grade students of SDN Jember Lor 1, which amounted to 26 students. Data collection techniques used include interviews, observation, tests and documentation. Data were analyzed using descriptive statistics and percentage presentations individually, classically and as an indicator.

The results showed the critical thinking skills of elementary school students in terms of students' mathematical abilities were in the moderate category with a classical average of 71.8. There are 50\% of students in the category of high critical thinking, $30.8 \%$ of students in the category of moderate critical thinking and $19.2 \%$ of students are in the low category.

The constraints experienced by the teacher in developing students' critical thinking skills are that some students are not accustomed to thinking systematically,
\end{abstract} 97 | JURNAL IKA VOL 8 No. 1 JUNI 2020 
students are not accustomed to giving reasons in solving problems or tend to be important to refer to the formula.

Keywords: Critical Thinking, Mathematic, Ability

\section{PENDAHULUAN}

Salah satu tujuan pembelajaran matematika di Sekolah Dasar yaitu siswa mampu memecahkan masalah dengan proses memahami, merancang dan memberikan solusi. Hal tersebut secara otomatis menjadikan matematika sebagai alat untuk berpikir. Tujuan pembelajaran matematika untuk membekali siswa memiliki kemampuan berpikir sesuai dengan perkembangan pembelajaran abad 21. Pembelajaran abad 21 ditandai dengan pembelajaran yang berpusat pada siswa. Siswa diharapkan memiliki empat kompetensi dalam pembelajaran abad 21. Empat kompetensi tersebut seringkali disebut 4C's meliputi creativitiy thinking atau berpikir kreatif, critical thinking atau berpikir kritis, collaboration atau kolaborasi dan communication atau komunikasi (Sunardi, dkk., 2017).

Hal ini semakin memperkuat bahwa pembelajaran matematika tidak cukup hanya mempelajari konsep atau hafalan. Pembelajaran perlu didesain agar siswa melakukan proses berpikir yang akhirnya siswa mampu menyelesaikan masalah dengan memberi solusi. Berpikir kritis bukan hanya dalam dunia ilmiah namun juga dalam kehidupan sehari-hari.

Kemampuan berpikir kritis atau critical thinking adalah proses berpikir mendalam, teliti dengan membandingkan berbagai informasi. Ennis (2011) menjelaskan bahwa berpikir kritis adalah proses berpikir untuk mengambil kesimpulan dengan berpikir aktif, teliti dan tidak terburu-buru. Hal ini berarti kemampuan berpikir kritis lantas tidak menjadikan siswa menerima atau menyimpulkan begitu saja suatu informasi namun perlu dipahami tanpa terburu-buru. Eggen \& Don (2012) menegaskan bahwa berpikir kritis bukan sebatas mampu menyimpulkan namun berdasarkan suatu assesmnen atau bukti-bukti. Orang yang berpikir kritis mamapu membuat kesimpulan dengan mengetahui informasi yang tepat, cara menggunakan informasi, mampu menemukan strategi relevan yang mendukung pemecahan masalah (Adinda, 2016).

Kemampuan matematika siswa merupakan kemampuan berdasarkan tes hasil belajar yang biasa dikategorikan dengan tinggi, sedang dan rendah Mengingat kemampuan siswa dalam pembelajaran Matematika berbeda-beda, tentu menjadikan siswa dalam berpikir kritis berbeda-beda. Perbedaan ini penting diketahui dan dipahami oleh guru agar dalam mengembangkan kemampuan berpikir kritis siswa lebih optimal 
dan tujuan pendidikan yaitu siswa menjadi pribadi yang mandiri, kritis dalam memecahkan masalah dapat tercapai. Oleh karena itu, dilakukan analisis kemaapuan berpikir kritis siswa Sekolah Dasar ditinjau dari tingkat kemampuan matematika siswa. kemampuan berpikir kritis mengacu pada Fisher.

\section{METODE PENELITIAN}

Penelitian ini menggunakan jenis penelitian deskriptif. Penelitian deskriptif merupakan penelitian yang mendeskripsikan suatu peristiwa atau fenomena secara terstruktur. Desain yang digunakan dalam penelitian ini yaitu deskriptif sederhana yang berarti mendeskripsikan apa adanya, nyata tanpa unsur manipulasi sesuai informasi dilapangan dengan tujuan memperoleh gambaran kemampuan berpikir kritis siswa Sekolah Dasar. Data yang digunakan dalam penelitian ini yaitu data kualitatif serta data kuantitatif.

Subjek penelitian ini yaitu siswa kelas V yang berjumlah 26 siswa dan 1 guru kelas V SD Negeri Jember Lor 1. Penentuan informan dipilih dengan teknik purposive sampling. Teknik purposive sampling adalah cara ilmiah dengan dengan pertimbangan dan tujuan tertentu (Sugiyono, 2009). Objek penelitian ini yaitu kemampuan berpikir kritis siswa kelas V SDN Jember Lor 1 dalam pembelajaran Matematika ditinjau dari kemampuan matematia siswa, upaya atau usaha guru dalam mengembangkan kemampuan berpikir kritis siswa, kesulitan yang dihadapi guru dalam mengembangkan kemampuan berpikir kritis siswa.

Data penelitian ini dikumpulkan dengan metode wawancara, observasi, tes dan dokumentasi. Wawancara dilakukan dengan siswa dan guru. Wawancara dengan siswa dilakukan untuk mengetahui pendapat siswa terhadap pembelajaran matematika yang diikuti selama ini. Wawancara dengan guru dilakukan untuk mengetahui kegiatan pembelajaran matematika yang biasa guru terapkan, mendapatkan informasi kemampuan berpikir kritis siswa serta tingkatan kemampuan matematis siswa. Observasi dilakukan untuk mengetahui kegiatan pembelajaran dengan guru dalam pembelajaran matematika. Tes diberikan kepada setelah dilakukan observasi. Soal tes yang digunakan berupa soal uraian yang terdiri atas 4 soal uraian. Setiap butir soal disesuaikan dengan indikator berpikir kritis meliputi mengidentifikasi, mengklarifikasi, menganalisis, mengvaluasi dan menyimpulkan. Dokumentasi diperlukan guna mengetahui tingkat kemampuan matematis siswa.

Instrumen pengumpulan data yang digunakan dalam penelitian ini yaitu 
triangulasi berupa pedoman wawancara berisi pertanyaan terkait pendapat siswa dalam pembelajaran matematika, usaha guru dalam mengoptimalkan pembelajaran matematika, serta pokok pertanyaan yang berkembang selama proses wawancara. Pedoman observasi kegiatan belajar siswa dan guru yang diberi check list untuk menjadikan observasi lebih mudah dan sistematis. Dokumentasi yang digunakan adalah hasil tes kemampuan matematis siswa. Pedoman penskoran tes kemampuan berpikir kritis siswa yang dirinci pada setiap indikator.

Pedoman penskoran indikator kemampuan berpikir kritis siswa dapat dilihat pada tabel 2.1 sebagai berikut:

Tabel 2.1 Pedoman Penskoran Indikator Kemampuan Berpikir Kritis Siswa

\begin{tabular}{|c|c|c|c|}
\hline \multirow[t]{2}{*}{ No. } & \multicolumn{3}{|c|}{ Kemampuan Berpikri Kritis } \\
\hline & Indikator & Deskriptor Skor & Skor \\
\hline \multirow[t]{4}{*}{1.} & \multirow{4}{*}{$\begin{array}{l}\text { Mengidentifikasi } \\
\text { (Siswa mampu merumuskan } \\
\text { informasi dengan jelas) }\end{array}$} & $\begin{array}{l}\text { Menyebutkan seluruh informasi yang ada } \\
\text { pada soal dengan benar }\end{array}$ & 4 \\
\hline & & $\begin{array}{l}\text { Menyebutkan seluruh informasi yang ada } \\
\text { pada soal namun ada beberapa yang salah }\end{array}$ & 3 \\
\hline & & $\begin{array}{l}\text { Menyebutkan seluruh informasi yang ada } \\
\text { pada soal namun semua salah }\end{array}$ & 2 \\
\hline & & Hanya menyebutkan beberapa informasi & 1 \\
\hline \multirow[t]{4}{*}{2.} & \multirow{4}{*}{$\begin{array}{l}\text { Mengklarifikasi } \\
\text { (siswa mampu menemukan } \\
\text { kembali pertanyaan penting } \\
\text { dalam permasalahan) }\end{array}$} & $\begin{array}{l}\text { Menemukan inti soal dengan lengkap dan } \\
\text { tepat }\end{array}$ & 4 \\
\hline & & Menemukan inti soal namun kurang lengkap & 3 \\
\hline & & Menemukan inti soal yang salah & 2 \\
\hline & & Tidak dapat menentukan inti soal & 1 \\
\hline \multirow[t]{4}{*}{3.} & \multirow{4}{*}{$\begin{array}{l}\text { Menganalisis } \\
\text { (siswa mampu menguraikan } \\
\text { strategi pemcahan masalah) }\end{array}$} & $\begin{array}{l}\text { Menentukan beberapa cara pemecahan soal } \\
\text { dengan tepat }\end{array}$ & 4 \\
\hline & & $\begin{array}{l}\text { Menentukan beberapa cara pemecahan soal } \\
\text { namun ada yang salah }\end{array}$ & 3 \\
\hline & & $\begin{array}{l}\text { Menentukan beberapa cara pemecahan soal } \\
\text { namun semua salah }\end{array}$ & 2 \\
\hline & & $\begin{array}{l}\text { Tidak dapat menentukan cara pemecahan } \\
\text { soal }\end{array}$ & 1 \\
\hline 4 & Mengevaluasi & Memberikan alasan yang logis dan tepat & 4 \\
\hline
\end{tabular}




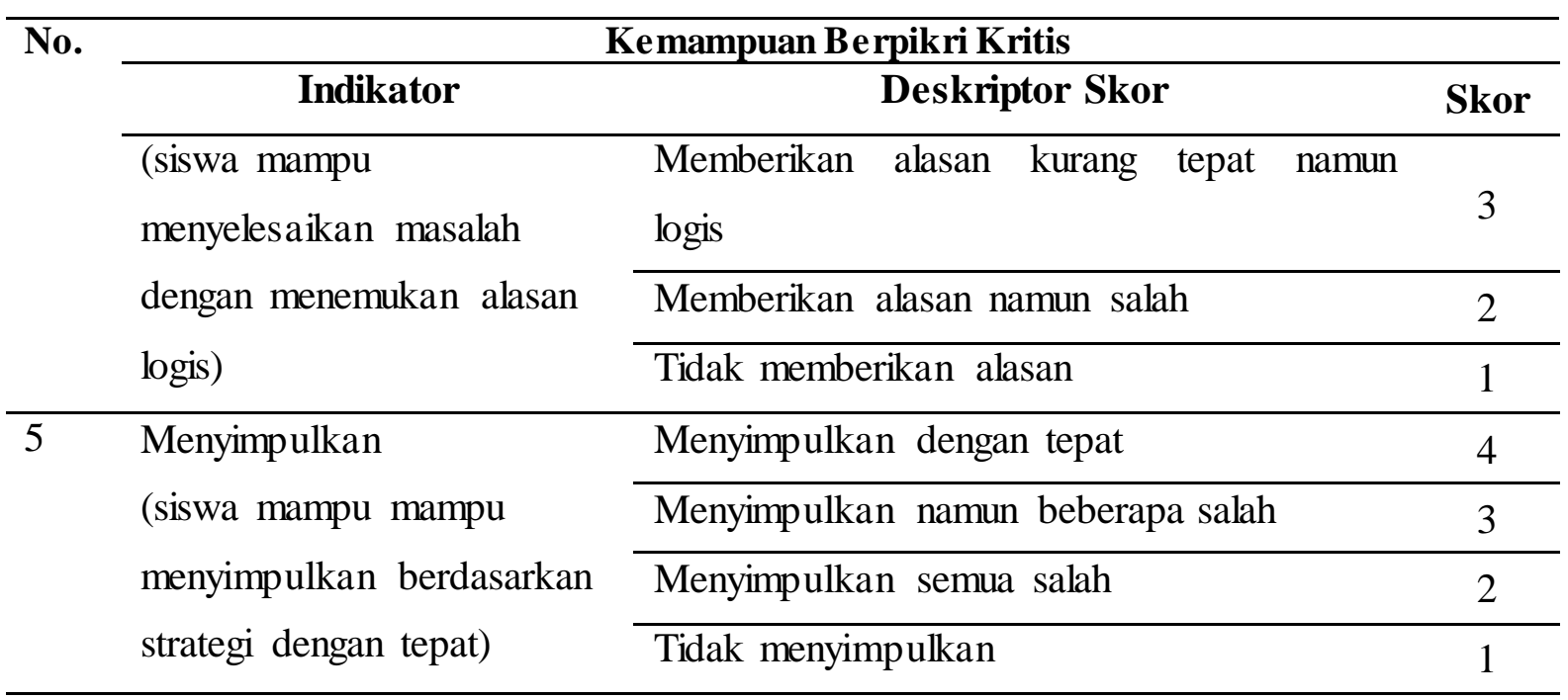

Sumber: Dikembangkan berdasarkan adaptasi (Fisher, 2007)

Analisis data pada penelitian ini menggunakan analisis data kualitatif dan kuantitatif. Analisi data kualitatif untuk mengolah data hasil wawancara, hasil dokumentasi dan hasil observasi. Analisis data kuantatif untuk mengolah data berdasarkan tes kemampuan berpikir kritis. Analisis data mencakup tiga tahapan yaitu mereduksi data, menyajikan data dan menarik kesimpulan (Sugiyono, 2013). Data skor hasil observasi kegiatan pembelajaran siswa dan guru dianalisis menggunakan indikator penskoran yang telah disediakan. Data skor hasil tes kemampuan berpikir kritis dianalisis dengan pedoman penskoran.

Hasil skor kemampuan kemudian dianalisis kembali secara individu, klasikal serta perindikator dengan rumus deskriptif presentase sebagai berikut:

$$
\mathrm{DP}=\frac{\mathrm{BP}}{\mathrm{BM}} \times 100 \%
$$

Keterangan:

DP = Deskriptif Presentase

$\mathrm{BP}=$ Banyak Indikator Terpenuhi

$\mathrm{BM}=$ Banyak Indikator Maksimal

Kemampuan berpikir kritis siswa yang telah dianalisis secara individu, klasikal dan perindikator diklasifikasikan berdasarkan kategori KEMENDIKBUD. Kategori kemampuan berpikir kritis dapat dilihat pada tabel 2.2 sebagai berikut: 
Tabel 2.2 Kategori Kemampuan Berpikir Kritis Siswa

\begin{tabular}{lll}
\hline \multicolumn{3}{c}{ Krategori } \\
\multicolumn{3}{c}{ Kemampuan Berpikir Kritis } \\
\hline $\begin{array}{l}\text { Rendah } \\
(<65)\end{array}$ & $\begin{array}{l}\text { Sedang } \\
(65-79)\end{array}$ & $\begin{array}{l}\text { Tinggi } \\
(80-100)\end{array}$ \\
\hline \multicolumn{3}{c}{ Sumber: } \\
\hline
\end{tabular}

\section{Hasil dan Pembahasan}

Hasil penelitian ini berupa diskripsi hasil tes kemampuan berpikir kritis siswa kelas V SDN Jember Lor 1, deskripsi upaya atau usaha guru dalam mengembangkan kemampuan berpikir kritis serta kesulitan yang dihadapi guru dalam mengembangkan kemampuan berpikir kritis siswa.

Tabel 3.1 Perolehan Skor Kemampuan Berpikir Kritis Siswa

\begin{tabular}{lllll}
\hline No. & $\begin{array}{l}\text { Kemampuan } \\
\text { Berpikir Kritis Siswa }\end{array}$ & Frekuensi & Presentase & $\begin{array}{l}\text { Rata-rata } \\
\text { klasikal }\end{array}$ \\
\cline { 1 - 3 } 1 & Tinggi (80-100) & 13 & $50 \%$ & $\begin{array}{c}71,8 \\
\text { (Sedang) }\end{array}$ \\
\cline { 1 - 3 } & Sedang (65-79) & 8 & $30,8 \%$ & \\
\hline
\end{tabular}

Berdasarkan tabel 3.1 Kemampuan berpikir kritis siswa Sekolah Dasar dengan subjek kelas V SDN Jember Lor 1 berada pada kategori sedang dengan nilai rata-rata klasikal yaitu 71,8. Artinya kemampuan berpikir kritis siswa sudah bagus namun masih belum memuaskan. Terdapat 13 siswa atau 50\% siswa berada pada kategori kemampuan berpikir kritis tinggi, 8 atau 30,8\% siswa berada pada kategori kemampuan berpikir kritis sedang dan 5 siswa atau 19,2\% siswa berada pada kategori kemampuan berpikir kritis rendah.

Kemampuan berpikir kritis siswa selanjutnya dianalisis perindikator untuk mengetahui pada kemampuan berpikir manakah yang paling dikuasai dan paling sulit bagi siswa. Hasil kemampuan berpikir kritis siswa perindikator dapat dilihat pada tabel 3.2.

Tabel 3.2 Perolehan Skor Kemampuan Berpikir Kritis Siswa Perindikator

No. Kemampuan Berpikir Kritis $\quad$ Skor $\quad$ Kategori perndikator 


\begin{tabular}{llll}
\hline 1. & $\begin{array}{l}\text { Mengidentfikasi } \\
\text { (Siswa mampu merumuskan informasi } \\
\text { dengan jelas) }\end{array}$ & 86.4 & Tinggi \\
\hline 2. & $\begin{array}{l}\text { Mengklarifikasi } \\
\text { (siswa mampu menemukan kembali } \\
\text { pertanyaan penting dalam } \\
\text { permasalahan) }\end{array}$ & 82.6 & Tinggi \\
\hline $3 . \quad \begin{array}{l}\text { Menganalisis } \\
\text { (siswa mampu menguraikan strategi } \\
\text { pemecahan masalah) }\end{array}$ & 79.8 & Sedang \\
\hline $4 . \quad \begin{array}{l}\text { Mengevaluasi } \\
\text { (siswa mampu menyelesaikan masalah } \\
\text { dengan menemukan alasan logis) }\end{array}$ & 57.6 & Rendah \\
\hline 5. & $\begin{array}{l}\text { Menyimpulkan } \\
\text { (siswa mampu mampu menyimpulkan } \\
\text { berdasarkan strategi dengan tepat) }\end{array}$ & 50.9 & Rendah \\
\hline
\end{tabular}

Berdasarkan tabel 3.2 diperoleh data bahwa kemampuan siswa berpikir kritis secara klasikal pada indikator satu yaitu mengidentifikasi memperoleh skor 86,4\% yang berarti siswa pada indikator mampu merumuskan informasi dengan jelas berada pada kategori berpikir kritis tinggi. Kemampuan siswa secara klasikal pada indikator kedua yaitu mengklarifikasi memperoleh skor $82,6 \%$ yang berarti siswa pada indikator mampu menemukan kembali pertanyaan penting dalam permasalahan juga dalam kategori tinggi. Kemampuan berpikir kritis siswa secara klasikal pada indikator ketiga yaitu menganalisis memperoleh skor $79,8 \%$ yang berarti siswa pada indikator mampu menguraikan strategi pemecahan masalah berada dalam kategori sedang. Kemampuan berpikir kritis siswa secara klasikal pada indikator keempat yaitu mengevaluasi memperoleh skor $57,6 \%$ yang berarti kemampuan siswa pada indikator menyelesaikan masalah dengan menemukan alasan logis masuk kategori rendah. Kemampuan berpikir kritis siswa secara klasikal pada indikator kelima yaitu menyimpulkan memperoleh skor $50,9 \%$ yang berarti kemampuan siswa pada indikator menyimpulkan berdasarkan strategi dengan tepat juga masih dalam kategori rendah. Kemampuan berpikir kritis siswa kemudian dianalisis dengan meninjau berdasarkan kemampuan matematika siswa.

Kemampuan berpikir kritis siswa ditinjau berdasarkan kemampuan matematika siswa dapat dilihat pada tabel 3.3.

Tabel 3.3 Kemampuan Berpikir Kritis Siswa ditinjau berdasarkan Kemampuan Matematika 


\begin{tabular}{|c|c|c|c|c|c|c|c|c|}
\hline \multirow[t]{2}{*}{ No. } & \multirow[t]{2}{*}{ Siswa } & \multirow{2}{*}{$\begin{array}{c}\text { Tingkat } \\
\text { Kemampuan } \\
\text { Matematika }\end{array}$} & \multirow{2}{*}{$\begin{array}{c}\text { Kategori } \\
\text { Berpikir } \\
\text { Kritis }\end{array}$} & \multicolumn{5}{|c|}{$\begin{array}{c}\text { Indikator } \\
\text { Berpikir Kritis }\end{array}$} \\
\hline & & & & 1 & 2 & 3 & 4 & 5 \\
\hline 1. & A & Tinggi & Tinggi & 4 & 4 & 4 & 4 & 3 \\
\hline 2. & B & Tinggi & Tinggi & 4 & 4 & 4 & 4 & 3 \\
\hline 3. & $\mathrm{C}$ & Tinggi & Tinggi & 4 & 4 & 4 & 3 & 3 \\
\hline 4. & $\mathrm{D}$ & Sedang & Sedang & 3 & 3 & 3 & 3 & 3 \\
\hline 5. & $\mathrm{E}$ & Sedang & Sedang & 4 & 4 & 4 & 2 & 1 \\
\hline 6. & $\mathrm{~F}$ & Sedang & Sedang & 4 & 4 & 4 & 3 & 2 \\
\hline 7. & $\mathrm{G}$ & Rendah & Rendah & 2 & 2 & 1 & 1 & 1 \\
\hline 8. & $\mathrm{H}$ & Rendah & Rendah & 2 & 2 & 2 & 1 & 1 \\
\hline 9. & I & Rendah & Rendah & 2 & 2 & 2 & 2 & 1 \\
\hline
\end{tabular}

Berdasarkan tabel 3.3 diperoleh temuan data bahwa secara umum siswa yang memiliki tingkat kemampuan matematika lebih tinggi baru menemukan kesulitan pada indikator berpikir kritis yang kelima yaitu menyimpulkan. Siswa dengan tingkat kemampuan berpikir matematika tinggi, memiliki kemampuan berpikir kritis yang tinggi hal nampak dari siswa sudah mampu dan lancar menemukan informasi fakta dalam soal (indikator berpikir kritis 1), siswa tidak kesulitan menemukan inti soal dan menuliskan dengan tepat (indikator berpikir kritis 2), siswa mampu menguraikan beberapa alternatif solusi (indikator berpikir kritis 3), sebagian besar siswa mampu memberikan alasan yang logis dari alternatif solusi yang diperoleh (indikator berpikir kritis 4), barulah pada saat membuat kesimpulan siswa mulai ragu atau bingung (indikator berpikir kritis 5) belum optimal.

Siswa dengan tingkat kemampuan matematika sedang dan kemampuan berpikir kritis sedang mulai muncul kesulitan pada indikator berpikir kritis tiga dan empat yaitu menganalisis dan mengevaluasi. Siswa bisa menemukan informasi fakta dalam soal, siswa mampu menemukan inti pertanyaan namun pada tahap menganalisis siswa sudah mulai muncul kesulitan. Siswa sudah mulai merasa sulit karena memang menganalisis sudah masuk berpikir kritis yang lebih kompleks. Hal ini sesuai dengan pendapat Kratwhol (Lewy, 2009) bahwa menganalisis memerlukan pemahaman pola yang mendetail dari hal kecil serta membuat struktur dari sebab akibat.

Siswa dengan tingkat matematika yang rendah dengan kemampuan berpikir kritis yang rendah rata-rata sudah menemukan kesulitan mulai indikator yang pertama 
yaitu mengidentifikasi. Siswa sudah kesulitan dalam menemukan informasi fakta, inti pertanyaan.

Kemampuan berpikir kritis siswa yang secara klasikal berada pada kategori sedang sudah pasti dikarenakan beberapa kendala.

Berdasarkan wawancara dengan guru diperoleh data bahwa kendala yang dialami guru dalam mengembangkan kemampuan berpikir kritis siswa yaitu beberapa siswa masih belum terbiasa berpikir secara sistematis, siswa belum terbiasa memberikan alasan dalam menyelesaikan soal atau cenderung yang penting mengacu pada rumus. Adanya kendala serta pentingnya kemampuan berpikir bagi siswa, guru melakukan beberapa usaha untuk mengembangkan kemampuan berpikir kritis siswa.

Usaha-usaha guru dalam mengembangkan kemampuan berpikir kritis siswa dengan menerapkan berbagai pendekatan pembelajaran salah satunya dengan pendekatan realistic mathematic education. Hal ini sesuai dengan hasil penelitian yang dilakukan (Amalia, 2019) bahwa kemampuan berpikir kritis siswa dapat meningkat dengan menerapkan pendekatan realistic mathematic education, selain itu guru melibatkan media-media mulai dari sederhana seperti kerta sampai pada media video agar siswa dapat melatih dalam bepikir, guru juga terus memberikan stimulasi dalam menganalisi menyelesaikan masalah. Hal ini sesui dengan hasil penelitian (Sigh \& Gupta, 2017) bahwa kegiatan menstimulasi ssiwa dalam menganalisis masalah dapat melatih siswa untuk berpikir luas.

Usaha yang juga dilakukan guru dengan mengembangkan soal dengan tipe high order thinking skills, guru juga melibatkan siswa dalam setiap diskusi pembelajaran. Usaha tersebut dapat mengembangkan kemampuan berpikir kritis siswa, sehingga siswa mampu menerapkan pengetahuan untuk mengevaluasi pemikitan mereka dalam seharihari. Hal ini sependapat dengan hasil penelitian (Alghafari \& Ismail, 2014). Guru juga megaskan dalam mengembangkan kemampuan berpikir kritis hindari langsung memberikan solusi pada siswa. Hal ini sesuai pendapat (Sa'dijah \& Sukoriyanto, 2013) tugas guru adalah membimbing siswa untuk membantu proses berpikir, sehingga lebih baik guru tidak memberikan solusi secara langsung

\section{KESIMPULAN}

Hasil analisis kemampuan berpikir kritis siswa sekolah dasar ditinjau dari tingkat kemampuan matematika siswa berada pada kategori sedang dengan rata-rata klasikal 71,8. Terdapat 50\% siswa berada pada kategori berpikir kritis tinggi, 30,8\% siswa pada kategori berpikir kritis sedang dan 19,2\% siswa berada pada kategori rendah. 
Berpikir kritis pada indikator mengidentifikasi memperoleh skor 86,4\%. Kemampuan berpikir kritis pada indikator mengklarifikasi memperoleh skor 82,6\% Kemampuan berpikir kritis pada indikator ketiga menganalisis memperoleh skor 79,8\%. Kemampuan berpikir kritis pada indikator keempat mengevaluasi memperoleh skor 57,6\%. Kemampuan berpikir kritis pada indikator kelima menyimpulkan memperoleh skor 50,9\%. Artinya sebagain besar siswa mampu berpikir kritis namun masih pada indikator tertentu teruama indikator mengidentifikasi dan mengklarifikasi. Siswa dengan tingkat kemampuan matematika yang tinggi memiliki kemampuan berpikir kritis yang tinggi pula. Temuan penelitian yaitu siswa dengan kemampuan matematika yang tinggi dan kemampuan berpikir kritis tinggi mulai menemukan kesulitan pada indikator berpikir kritis keempat dan lima, sedanagkan siswa dengan tingkat kemampuan matematika sedang dan kemampuan berpikir kritis sedang mulai menemukan kesulitan pada indikator berpikir kritis ketiga dan keempat.

\section{DAFTAR PUSTAKA}

Adinda, A. 2016. Berpikir Kritis dalam Pembelajaran Matematika. Jurnal Logaritma.

Alghafari, A. \&. Ismail, H.N.B. 2014. The Effects of Integrating Creative and Critical Thinking on Schools Students Thinking. International Journal of Social Science and Humanity.

Amalia, N.F. 2019. Kemampuan Berpikir Kritis Siswa melalui Penerapan Pendekatan Realistic Mathematics Education Berbantuan Media Manipulatif Origami. Journal UM.

Assaly, I.R., \& Smadi, O.M. 2015. Using Bloom's Taxonomy to Evaluate the Cognitive Levels of Master Class Texbook's Questions. Journal of English Language Teaching.

Eggen, P., \& Don, Kauchak. 2012. Strategi dan Model Pembelajaran Mengajarkan Konten dan Keterampilan Berpikir. Jakarta: Indeks

Ennis, R.H. 2011. The Nature of Critical Thinking: An Outline of Critical Thinking Dispositions and Abilities. This is a Several-Times-Revised Version of a Presentations at the Sixth International Converance on Thinking at MIT. Cambridge.

Fisher, A. 2007. Berpikir Kritis sebuah Pengantar. Jakarta: Erlangga

Hallatu, Y., Prasetyo, K., Haidar, A. 2017. Pengaruh Model Problem Based Learning terhadap Kompetensi Pengetahuan dan Keterampilan Berpikir Kritis Siswa Madrasah Aliyah BPD Iha tentang Konflik. Jurnal Penelitian Pendidikan

KEMENDIKBUD . 2016. Peringkat dan Capaian PISA Indonesia Mengalami Peringkatan 
Lewy. 2009. Pengembangan Soal untuk Mengukur Kemampuan Berpikir Tinggi Pokok Bahasan Barisan dan Deret Bilangan di Kelaa IX SMP Xaverius Maria. Palembang

Sa'dijah \& sukoriyanto. 2013. Asesmen Pembelajaran Matematika. Malang: UM Press.

Singh, R. \&. Gupta, M.P. 2017. Comprehensive Asessment of Student Outcomes in Various Learning areas if the 5th Graders in Mathematics. Imprerial Journal of Interdisciplinary Research (IJIR) .

Stobaugh, R. 2013. Assesing Critical Thinking in Middle and High Schools: Meeting the Common Core. Dalam R. Stobaugh, Assesing Critical Thinking in Middle and High Schools: Meeting the Common Core. New York: Routledge.

Sugiyono. 2009. Metode Penelitian Kuantitatif, Kualitatif dan R\&D. Dalam Sugiyono, Metode Penelitian Kuantitatif, Kualitatif dan R\&D. Bandung: CV. Wacana Prima.

Sugiyono. 2013. Metode Penelitian Pendidikan (Pendekatan Kualitatif, Kuantitati dam $R \& D)$. Bandung: Alfabeta.

Sunardi,Kurniati, D., Sugiarti, T., Yudianto, E. 2017. Pengembangan Indikator 4'Cs yang Selaras dengan Kurikulum 2013 pada Mata Pelajaran Matematika. Prosiding AdMathEdu.

Wahid, I.Z. 2012. Pembelajaran Matematika dengan Media Pohon Mate,atika pada Materi Operasi Hitung Bilangan Bulat. Jurnal Cakrawala Pendidikan. 